\title{
The Collaborator Mesmerized by a Nationalist: The Narrative Configuration of Nationalism and Colonial Modernity in the South Korean Film, "Modern Boy" (2008)
}

\begin{abstract}
By Min Koo Choi ${ }^{*}$
In this paper, I will examine the trope of the conflicting voices of nationalism and colonial modernity that are articulated in the narrative of the Korean film "Modern Boy," released in 2008 in South Korea. The reconstruction of Kyŏngsŏng (Seoul in Contemporary Korea) under Japanese colonial rule as a modern urban city is paralleled with Japanese surveillance and oppression over the Korean people who were seen as a possible threat. These conflicting tropes are expressed narratively through a love affair between a nationalist and a Japanese collaborator, in that the voice of the female character as a militant independent fighter competes with and contests the voice of the male character as a Japanese collaborator, which highlights the stability and happiness of the independent individual life. Modernity is the common denominator determining the two main characters' identities, but they have not completely embraced or been subsumed by either nationalism or collaboration.
\end{abstract}

\section{Introduction}

Korean history, as it regards Japanese colonial rule, has played a role in raising Korean national consciousness, and the vestiges of Japanese colonial rule have been regarded as an obstacle to eliminate in order to build up a modern nation state. The way in which Japan established and perpetuated Japanese colonial rule over Korea had a character that was distinct from other colonial enterprises in which Western imperialism colonized non-Western people. Both Korea and Japan developed their identities and tradition under the Sinitic world order in East Asia until the emergence of Western imperial power in the nineteenth century encroached on this order with their advanced military technology. Under the threat of Western imperial power, Japan went through modernization successfully and became a formidable imperial power in East Asia. Japan competed with and defeated China and Russia, and formally colonized Korea in 1910. Koreans, who regarded Japan as less civilized under the standards of the Sinitic world order, experienced their traditional values and identity being downgraded as uncivilized and inferior, and the Korean people's autonomous program of modernization was frustrated. This was traumatic to the Korean people's pride and identity.

\footnotetext{
* Assistant Teaching Professor, Georgetown University, USA.
} 
The Japanese colonial period (1910-1945) has been frequently revisited as a cinematic setting and topic for South Korean filmmaking. The South Korean films produced after the liberation from Japan in 1945 have faithfully reflected a nationalistic view in the cultural/discursive field of Korea. The narrative plots are interlaced in the schematic representation of the Japanese colonial area as the Japanese exploitation of Korea and the victimization of the Korean people. However, the nationalistic trend that centrally positions Korean resistance against Japanese colonial rule in the development of narrative plot has been changing in the films that have been released after $2005 .{ }^{1}$ These films focus on depicting the everyday lives of Korean people and presenting individuals who pursue their own desires and dreams in conflict with the historical backdrop in the arena of colonial Korea. The conflict and resolution of the film strays from the predominant nationalist historical perspective. This phenomenon coincides with the new trend of scholarship, which looks at the everyday lives and cultures of Korean people under Japanese colonial rule. ${ }^{2}$ The theory of colonial modernization against the dominant nationalist historical perspective has precipitated lively debates in Korean scholarship. The postmodern and postcolonial theories that were introduced to South Korea in the 1990s also began to question and challenge the nationalistic historical viewpoints. This academic trend may have an impact that shifts the emphasis of film representation from a nationalistic viewpoint to the more varied aspects of colonial Korea.

The film "Modern Boy," released in 2008 in South Korea, illuminates the changing perspectives of South Korea, and depicts its colonial history under Japanese colonial rule by drawing upon two conflicting viewpoints. In the film, colonial Korea is presented as two separate realms that collude and co-exist. The world of the main character, Haemyŏng, is the reflection of colonial modernity where Kyŏngsŏng (Seoul in the present) is described as an urban city where modern infrastructure is successfully facilitated and modern culture blossoms. Haemyŏng, who was educated in Japan, worked for the colonial government and enjoyed a participation in modern conventions offered by the urban city of Kyŏngsŏng. His family itself represents the Japanese collaborators who possess economic means and political power by collaborating with Japanese colonial authority. On the other hand, the film also depicts the Japanese colonial rule's oppression of the Korean people and the Korean people's resistance in the nationalist paradigm, through another main character, Nansil. The collusion between two worlds through their love relationship provides the momentum of narrative plot development. The embodiment of two main characters through their love affair, in tandem with their interaction with the social reality of Japanese colonial rule, illuminates a

1. Sunghwan Yi, "Shingminji Kŭndae'ŭi Yŏnghwajŏk Chaehyŏnŭl T'onghan Han'guk Sahoeŭi Inshik" ["The Perception of Korean Society Displayed in the Representation of 'Colonial Modernity' in Korean Film"], Yŏnghwayŏn'gu, 41 (2009): 105-126.

2. Hyŏngrae Cho, "Modŏn Poi Modŏn Kŏl Maŭmkkŏt Chŭlgira' Shingminji Sojae Yŏnghwa Pum"["Modern Boy, Modern Girl, Enjoy as Much as You Can' the Boom of Films Set in Colonial Korea"], Kyŏnghyang Sinmun, October 2, 2008. http://bit.ly/1OCFDjj. 
microscopic aspect of colonial Korea in which the assertion of the desires of the individual emulates the collective identity of the Korean nation.

\section{Nationalistic Discourse and Colonial Modernity of Japanese Colonial Rule in Korea}

The way of looking at Japanese colonial rule in Korea is a crucial issue that intersects with modernity and nationalism as they have emerged in Korea. South Korean nationalist scholarship attempts to separate Japanese colonialism from modernity and nationalism. Throughout South Korea's successful transformation into a developed country in a relatively short period of time, the building up of a modern nation-state should be the unadulterated goal and objective. The conventional formula of the nationalist scholarship is to look at Japanese colonial rule as Japanese exploitation of Korea, and the Korean people's resistance plays a role in the historical framework which posits Japanese colonial rule as the epoch of a great obstacle that Korean people challenged and overcame through their resistance. This eventually resulted in the building up of a modern nation-state. ${ }^{3}$ Modern infrastructure facilitated by Japanese colonial rule is downgraded as the by-product of Japanese colonial rule used to exploit Korea more effectively, and there is an emphasis on the isolation of the majority of Korean people from modern transformation implemented by Japan. ${ }^{4}$ Despite its difference from the Western modern nation-state, through a long history, Koreans developed a collective identity in a unified political system, and shared a culture that became the basis for a vision of the modern nation in Korea. ${ }^{5}$ Nationalist historians have attempted to search for the socio-historical evidence and interpretation to prove that the premodern Korean society, the Chosŏn dynasty, would inevitably have developed into a Western-style modern nation-state through a capitalistic economic system and industrialization without the Japanese colonization of Korea. ${ }^{6}$ In opposition to the Korean nationalist historiography, the concept of colonial modernization emerged in South Korea in the 1980s. Focusing on the analysis of the modernization process in the economic sector, economic historians questioned the Korean nationalist's claim for the capitalistic development in premodern Korea, and acknowledged the economic development that occurred

3. Yŏnt’ae Chŏng, "'Singminji Kŭndaehwaron'Nonjaengŭi Pip'an'gwa Shin'gŭndaesaron Mosaek" ["The Debate on the Theory of Colonial Modernization and Proposal for New Paradigm of Modern History"], Ch'angjakkwa Pip'yŏng, 27, no. 1 (1999): 354-356.

4. Hong Yung Lee, "Introduction: A Critique of "Colonial Modernity," in Colonial Rule and Social Change in Korea 1910-1945, ed. Clark W. Sorensen, Yong-ch'ul Ha, and Hong Yung Lee, (Seattle: University of Washington Press, 2013), 8-10.

5. Hunggyu Kim, Kŭndaeŭi T'ǔkkwŏnhwarŭl Nŏmŏsŏ [Overcoming the Privilege of Modernity] (Seoul: Ch'angjakkwa Pip'yŏng. 2013), 73-80. $1-6$.

6. Carter J. Eckert, Offspring of Empire (Seattle: University of Washington Press, 1991), 
in Korea under Japanese colonial rule. ${ }^{7}$ These two different viewpoints on colonial Korea precipitated heated debates in Korea in the 1990s.

Since 1990s, the perspective of colonial modernity influenced by postmodern and postcolonial theory began to call into question the limited scope of the kind of scholarship that considered Western modernity and capitalist development to be the criteria with which to analyze colonial Korea. The universality of Western modernity has been challenged, along with the dichotomy of either Japanese exploitation or modern development in colonial Korea and a grand narrative of colonial history contingent on a macro-analysis of political movements and economic structures. ${ }^{8}$ Shin and Robinson's book Colonial Modernity in Korea, ${ }^{9}$ representing this new approach, pays attention to colonialism, modernity, and nationalism, and the ways in which these three themes intertwine. Rather than positing modernity as the natural development of Korean history that was distorted by colonialism, they see modernity not as a universal concept, but as a Western phenomenon that was introduced to Korea in the form of colonialism. A new collective identity as a modern nationstate, which Koreans have continued to imagine and construct, is the Korean people's response to colonialism and modernity. This view, however, also admits that the Korean people's construction of a nation is not so much the mere import of foreign concepts as it is the Koreans' own creative reconstruction of a traditional repository of collective culture and history that pre-dated Korea's encounter with modernity. Japanese colonial rule also operated through an attempt to dominate the hegemony of the cultural sphere. In this sense, Japanese colonial rule in Korea created the arena where Korean people as the colonized interacted with Japanese colonial rule as the colonizer through contestation and negotiation that influenced and changed both the colonized and the colonizer. In this sense, colonial modernity can be a useful concept with which to indicate the unique character of the origin of Korean modernity that was shaped and formed in response to Japanese colonial rule. Modern cultural and economic infrastructure, as it was facilitated by Japanese colonial rule, allowed social mobility for some Korean people, and also isolated other Korean people from its effects. It was also part of the apparatus of Japanese colonial rule to become a space for the formation of a national consciousness of Korean people in opposition to it. ${ }^{10}$ The focus of South Korean scholarship in the 2000s began to shift to the socio-cultural history of colonial Korea and the everyday lives of Korean people under Japanese

7 . Yŏngho Yi, "'Naejaejŏk Palchŏnnon' Yŏksainshigŭi Kwejŏkkwa Chŏnmang" ["Genealogy and Prospect on the Perception of Indigenous Development Theory"], Han'guksayŏn'gu, 152 (2011): 260-263.

8. Younghan Cho, "Colonial Modernity Matters?: Debates on Colonial Past in South Korea," Cultural Studies 26, no. 5 (2012): 651.

9. Gi-Wook Shin and Michael Robinson, "Introduction: Rethinking Colonial Korea," in Colonial Modernity in Korea, ed. Gi-Wook Shin and Michael Robinson, (Boston: Harvard University Press, 1999), 1-18.

10. Haedong Yun, Shingminjiǔi Hoesaekchidae [The Gray Area in the Colony], (Seoul: Yŏksabip'yŏnsa, 2003), 39-49. 
colonial rule through the analysis on discourses and culture. ${ }^{11}$ This scholarship emphasizes the ways in which colonial power operates in people under the influence of colonialism, both the colonizer and the colonized, and how people have responded to it.

\section{The Modern Boy and Modern Girl in Colonial Modern Korea}

The depiction of Kyŏngsŏng (contemporary Seoul of South Korea) as the large modern city, and of Korean people with modern fashions and lifestyles, brings to light the issues of colonial modernity, and the question of whether Korea went through modern transformation under Japanese colonial rule, or the Japanese colonial government merely pillaged Korea. The film, aided by CGI techniques, recreates Korea in 1937. Surrounding the Japanese colonial government building, the symbol of Japanese colonial rule in Korea, the urban landscape of Kyŏngsŏng extends throughout the film. It also depicts Kyŏngsŏng as the large metropolitan city where the commercial districts, surrounded by modern buildings, were crowded with various people that can be distinguished and identified by their clothing, such as Western suits, Japanese traditional costumes, and Korean traditional costumes. The trolley car goes through the center of the city intersected by a car and a rickshaw. The Kyŏngsŏng train station, where Haemyŏng meets Shinsuke who is coming from Japan as a prosecutor for Japanese colonial government in Korea, also indicates that Kyŏngsŏng has emerged as the center of Korea as a Japanese colony that is connected to metropolitan Japan. The film also captures modern cultural facilities, such as the Mitsukoshi department store, the Western restaurant, Myŏngdŏng Cathedral, a café, and a club. This mesmerizing Kyŏngsŏng sheds a light on the colonial modern facilities and infrastructure that have been developed under Japanese colonial rule. However, the depiction of the urban city of Kyŏngsŏng is mostly limited to the southern town where the urban development is concentrated, because Japanese residents resided in the southern part of Seoul divided by a stream, Ch'onggye. On the contrary, the film under-represents the northern town by showing shabby thatched houses momentarily, but taking a lot of time to show the glamour of the city landscape. The northern town populated by Koreans had been underdeveloped during the Japanese colonial period. ${ }^{12}$ The setting of the narrative events mostly occurs in the southern town.

In the mid-1920s, the new cultural figures of the Modern Boy and Modern Girl emerged in the discourses of the cultural sphere such as newspapers and journals. In contrast with the modern male intellectual and the New Woman ${ }^{13}$

11. Yonson Ahn, "The Colonial Past in Post-colonial South Korea: Colonialism, Modernity and Gender," in Contested Views of a Common Past, ed. Steffi Richter, (Frankfurt/New York: Campus Verlag, 2008), 173-175.

12. Baek Yung Kim, "Ruptures and Conflicts in the Colonial Power Bloc: The Great Keijo Plan of the 1920s," Korea Journal, 48, no. 3 (2008): 10-40.

13. The group of women educated in accordance with the criteria of the New Woman emerged in Korea in 1920s. These Korean New Women observed the women's movement led 
who were identified as the agents of the modernization of Korea, the Modern Boy and Modern Girl are often seen as apolitical cultural icons often associated with the consumption and enjoyment of the benefits of modern culture, such as western hairstyles, fashion, and pop culture, and love and sexual freedom. In particular, the Modern Girls became the object of the public gaze, and were viewed with both desire and caution, because of their sexual attraction. ${ }^{14}$ Journalists and literary writers regarded them as a possible threat to the morality of family and marriage, and attempted to admonish them through their writings. ${ }^{15}$ However, the group of people who can be classified as Modern Girls in the West and in Japan, who were middle-class women with a modern education and with economic independence through their jobs, had hardly emerged in Korea during Japanese colonial rule. ${ }^{16}$ The Modern Girl is a rather discursively shaped entity, imported from Japan and disseminated through the discursive sphere in the 1920s and 1930s, that young women imitated and aspired to. The term Modern Girl was used to indicate a wide range of women, such as female students, working girls in the modern infrastructure, Kisaeng ${ }^{17}$ and the Café Waitress ${ }^{18}$ who embodied the "modern look" ${ }^{19}$ of Korean

by Seitō in the 1910 s while studying abroad in Japan. The term New Woman began to be widely used from 1920 and expanded the scope from a small number of well-known women intellectuals to women educated at least in the secondary modern school. See Kyŏngil Kim, Yŏsŏngŭi Kündae, Kündaeŭi Yŏsŏng [Women's Modernity, Women of Modernity] (Seoul: P'urŭnnyŏksa, 2004), 24-28.

14. Hyaeweol Choi, The New Woman in Colonial Korea: A Sourcebook (New York: Routledge, 2013), 12.

15. Sang-ho Ro, "Café Waitresses and Disharmony: 'Erotic Grotesque' Aestheticism in 1930s Colonial Korea," Journal of Alternative Perspectives in the Social Sciences, 4, no. 4 (2012): 729-756.

16. The Modern Girl is the cultural icon characterized as a self-asserting women with new fashions, the pursuit of sexual freedom, and modern consumerism, and appeared around the world in the1920s and 1930s. They challenged social order based on patriarchy. Women that can be classified as Modern Girls in Korea included women engaged in commerce and service sectors and professional jobs. However, the number of those women was very small. As for the statistical data of working women in colonial Korea, see Sujin Kim, Shinnyŏsŏng, Kŭndaeŭi Kwaing [The New Woman, The Excess of Modernity], (Seoul: Somyŏngch'ulp'an, 2009), 283 290 .

17. Kisaeng refers to the entertaining woman who provides companionship and sex for the aristocracy, called Yangban in the Chosŏn Dynasty. Through Japanese colonial rule (19101945), they served the male customers with their professional skills in traditional music and dance in a traditional form of banquet. However, they also had been agents for the realization of modern fashion and modern love during the time of Japanese colonial rule (1910-1945), and were emulated by female students. See Bodŭre Kwŏn, Yŏnaeŭi Sidae [Age of Love] (Seoul: Hyŏnshilmunhwayŏn'gu, 2003), 40-53.

18. The café waitress emerged in the 1930s and provided companionship for the male customer who visited a western style café for food and drink, and the companionship of women. They dressed up in western style clothes and had western hairstyles and make-up. See Sang-ho Ro, "Café Waitresses and Disharmony: 'Erotic Grotesque' Aestheticism in 1930s Colonial Korea," Journal of Alternative Perspectives in the Social Sciences, 4, no. 4 (2012): 732-735.

19. The term "modern look" is borrowed from Dong's article in her analysis of the Chinese Modern Girl. It is a useful term for characterizing the Modern Girl phenomena in a way that is not limited to the discursive sphere. In the Korean context, the Modern Girl is a 
society. ${ }^{20}$ In reality, the group of people who could emulate the icon of the Modern Boy and Girl were in this sense, sons of the upper-class families who flourished during Japanese colonial rule, and the women who were engaged in the entertainment professions, such as the Kisaeng and the Café Waitress. The Modern Girls especially, coexisting with the term New Woman in the discursive sphere in the 1920s and 1930s, function as the embodiment of the negative connotations of the educated women. ${ }^{21}$

In the film, the main character Haemyŏng belongs to the realm of the bright side of colonial modern Korea. In many aspects, he is qualified as having the conditions of the Modern Boy described above. First of all, he has had a modern education at Tokyo Imperial University, which represents the highest educational attainment in the Japanese empire. Haemyŏng has worked for the Japanese colonial government as a bureaucrat. The department that he is working in is in charge of urban planning that is involved with the development and maintenance of Kyŏngsŏng. He does not show any social and political consciousness about Korea under Japanese colonial rule. Strictly speaking, he is neither a nationalist nor an active Japanese collaborator. He does not even seem to take his job seriously, but shows a delinquent attitude while on duty, and gives important information to his father in return for the extra allowance with which he indulges in the luxurious aspects of modern life realized in morning coffee, Western suits, driving a car, hanging out with women, and enjoying night life in cafés and clubs. His upper-class family background also indicates its emergence through the collaboration with Japanese colonial rule. His father is also a former nationalist, but has become a Pro-Japanese collaborator, and he donates money for the Japanese empire's war effort. Moreover, he has accumulated wealth through his investment in real estate with the information given by Haemyŏng. In this sense, Haemyŏng's father is a beneficiary of Japanese urban development in Korea. Haemyŏng's family represents Koreans who were originally attracted to and associated with modern development, but ended up being Japanese collaborators. For them, Japan is the civilization of modernity and a source of power and stability.

Nansil can also be qualified as one who emulates the cultural icon known as the Modern Girl. First of all, she is cultivated in modern culture. Initially, she draws Haemyŏng's attention through her performance of singing and dance in the club located in Kyŏngsong. Moreover, she is also working at a high-class dress shop as a skilled tailor. Her splendid Western fashion that is expressed throughout the film also displays her modern tastes that can be seen as comparable to the tastes of the Modern Boy, Haemyŏng. Also, her various jobs

cultural icon that can hardly be attained by them explicitly in a material sense, but the "modern look" was a real substance in colonial Korea that different groups of women imitated and aspired to. See Madeleine Yue Dong, "Who Is Afraid of the Chinese Modern Girl?," in The Modern Girl Around the World, ed. The Modern Girl around the World Research Group, (Durham: Duke University Press, 2008), 194-219.

20. Chiyŏng So, "Shingminji Chosŏnŭi Modŏn'gŏl" ["The Modern Girl in Colonial Korea"], Han'gukyŏsŏnghak, 22, no. 3 (2006): 199-228.

21. Sujin Kim, Shinnyŏsŏng, Kŭndaeŭi Kwaing [The New Woman, the Excess of Modernity] (Seoul: Somyŏngch'ulp'an, 2009), 284-290. 
related to modern infrastructure indicate her financial independence, that is distinguished from traditional housewives and the New Woman engaged in education and social movements. Her courtship with Haemyŏng also indicates the sexually open character of the Modern Girl, which is often downgraded as the possible agent of a demoralizing force, because of sexual looseness and corruption. When Nansil feels attracted to Haemyŏng, she does not hesitate to sleep with him after meeting a couple of times. Compared with social morality and restraint of a woman's sexuality in the name of chastity at that time, she does not show any sense of guilt and reluctance toward Haemyŏng's approach and the development of their sexual relationship. Furthermore, she does not relate her sexual relationship with any ground of future marriage. Nansil is merely faithful to her emotions and desires without confining her relationship to any socially accepted union. However, her hidden identity as a nationalist who plans to assassinate high-ranking colonial government officials provides a more complicated characterization of Nansil that is not limited to the personality of an apolitical Modern Girl.

\section{The True Face of Japanese Colonial Rule as It is Exposed to Haemyŏng}

Haemyŏng's pursuit of his own identity as a Korean is paralleled with his finding Nansil's whereabouts and getting to know her. Even though it is accidental that he falls in love with Nansil, the more he is drawn to Nansil, the more he recovers his identity as a Korean. Haemyŏng's pursuit of Nansil and his attempt to find her true identity that has been hidden from him becomes the turning point for him to transform into a nationalist. His motive for pursuing Nansil is blind to his own emotion that has attracted him to Nansil. However, Nansil is depicted as a mysterious figure whose true identity is blocked from Haemyŏng. The more he wants to know Nansil's true identity, the more she is unreachable for him. Her identities shift from music entertainer, to a tailor in a western dressmaking shop, to a surrogate singer for famous Japanese singers, to a resistance fighter against Japanese colonial rule. Her multi-identities blocked Haemyŏng from knowing and possessing her in his world. Each short meeting puts him in an awkward position that is followed by Nansil's disappearance. Also, his pursuit of Nansil in order to know her true identity brings him into unanticipated involvement with independent resistance activity, and this challenges and calls into question his own subject position that he has never speculated about seriously. Through his relationship with Nansil, Haemyŏng begins to see the oppressive side of colonial Korea.

Nansil's plan to commit an assassination is exposed through the investigation of her cousin brother. At first, it is the scheme of Haemyŏng supported by his friend Shinsuke in order to create a connection with Nansil after Haemyŏng becomes enamored with her at the club. However, Shinsuke, who is a Japanese prosecutor in the Japanese colonial government, finds out about Nansil's connection with anti-colonial activities through her cousin brother. With the explosion of Haemyŏng's lunch box prepared by Nansil at 
his work- place, the Japanese colonial government building, he becomes a suspect and an important source of information regarding Nansil and her plan. He turns from the upper class in colonial Korea to become a Korean suspect who can be a potential obstacle to the continuation of Japanese colonial rule. Through the investigation, Haemyŏng eventually knows that he cannot be more than Korean. He is maltreated and suffers torture by Japanese investigators as he is forced to confess Nansil's whereabouts. His best friend Shinsuke allows the Japanese investigator to treat Haemyŏng as they did other Korean suspects, and furthermore, Shinsuke himself slaps Haemyŏng's cheek when he investigates him. This is the point at which Haemyong eventually realizes that there are fundamental differences between him and Shinsuke, Japanese and Korean, the colonizer and the colonized. The bifurcation from his bond with his best friend Shinsuke provides him with a reflection of his own identity as a Korean who can never be treated equally with the Japanese. Haemyŏng begins to recognize the difference between Korean and Japanese before this incident, as is shown in the conversation with Nansil. When Nansil asks him what dream he had in his youth as a way of persuading him to live a meaningful life rather than indulging in personal interests and extravagant lifestyles, Haemyŏng says that he wanted to be a Japanese man. It is a kind of identity that Haemyŏng pursues through his life in order to become an example of a Modern Boy, but he cannot achieve it because he is not Japanese, but a colonized Korean.

As Haemyŏng becomes involved with Nansil, the film shows how the mechanism of Japanese colonial rule operates. Inside the bustling city, the Japanese Surveillance through the judicial branch represented by Shinsuke and the Japanese police regulates all classes of people living under Japanese colonial rule in Korea. As Nansil's cousin brother's case indicates, the Japanese police investigator can arrest and torture the suspect without any rigorous evidence. The regulation and control over individuals can be applied partially to Koreans and Japanese when the police investigator in search of Nansil in the illegal gambling house asks all the guests to form two lines, for Japanese and Koreans. The people in the Korean line are slapped by the detective when he interrogates them. Kyŏngsŏng is the symbol of the modern transformation of Korea as maintained by the implementation of order under Japanese colonial rule by brutal means of surveillance and violence. When Haemyŏng is released from the investigation and torture by those seeking the whereabouts of Nansil, he encounters a group of marching Japanese soldiers who embody the military aspect of Japanese colonial rule. The setting of the film in 1937 functions as the historical allegory of Japanese military expansionism through Korea, since Japan invaded the mainland China in 1937. With Japan's invasion of China, the Japanese colonial government mobilized Korea as the basis of its colonial expansion, and strengthened its control over Korean society and its people. When Haemyŏng brings Nansil's cousin brother, who becomes mentally ill due to the after-effects of the torture, to Myŏngdong Cathedral, the Korean people, who appear to be shabby and helpless as they pray to overcome their hardships, eventually come to Haemyŏng's mind. They are Korean people who suffer under Japanese 
colonial rule. This explicitly indicates that Haemyŏng develops empathy for fellow Koreans with whom he has lived in the same spatial and temporal arena, but who have not been necessary for him to notice. In the Myŏngdong Cathedral, the camera focuses on the bandage on the cousin brother's ear, and this is paralleled with Hamyong's, which covers the scar of the wound left by Japanese investigators as a means of torture. The scars and trauma of the torture of Nansil's cousin brother eventually come to his attention, and he empathizes with the victim, since he has gone through the same investigative procedure accompanied by torture. This is the turning point when Haemyong comes to see the gloomy side of colonial Korea, and realizes that he does not have the privilege of being immune from colonial reality.

\section{The Configuration of a Love Relationship and Haemyŏng's Transformation}

The film depicts free love between Haemyŏng and Nansil in the landscape of colonial Korea as attractively modern, and the pursuit of love is posited as convincing and significant to the character's path. The culture of modern love is the important factor that binds Haemyŏng with Nansil. In spite of their conflicting values and commitments as a collaborator and a nationalist resister, they share personal tastes and a preference for modern culture. It is clear that their love relationship is furnished within the modern cultural sphere allowed by Japanese colonial rule. Their different world views in regard to nationalism do not prevent them from falling in love with each other. As a Modern Boy and Girl, they float around the city of Kyŏngsŏng and enjoy their relationship by means of modern conventions, such as modern music, dance, and Western wine.

The conflict between Haemyŏng and Nansil, however, arises and is perpetuated through their relationship because of their different identities and pursuits. The characterization of Nansil in the film turns out to be more complicated as she is also a nationalist, and is deeply involved in the armed resistance movement. Nansil exploits her talent for modern fashion and music in order to camouflage her identity and plan the assassination of the highranking officials in the Japanese colonial government. This is a new kind of character that is thrust upon a Modern Girl, and contrasts with the depiction and representation of the Modern Girl in the 1920s and 1930s. On the surface, she is a good match with Haemyŏng, because of her tastes and preference for modern culture. However, their political commitments, which derive from their identities as a nationalist resister and a Japanese collaborator, are necessarily contradictory. Rather than seeking economic success and political power, Haemyŏng is depicted as a naïve Modern Boy who is apolitical, and displays blind commitment to modern culture. His collaboration with Japanese colonial rule is paralleled with the origin and the perpetuation of modern culture associated with Japanese colonialism. The modern apparatus that Haemyonng enjoys is inextricably linked with his education, job, and the prosperity of his 
family originating in Japanese colonial rule. In this sense, Nansil's world and Haemyŏng's world contain a fundamental difference that cannot be harmonized.

The union of the Modern Boy and the nationalist comes to a crisis as Nansil gives shape to her plan to assassinate the high-ranking colonial government officials. The future and the continuation of their love relationship is hindered by their different responses to Japanese colonial rule. And it produces a new predicament for Nansil, who is caught between the pursuit of individual happiness with Haemyŏng, and the collective good, such as national independence from Japanese colonial rule. Haemyŏng's world view continues to collide with that of Nansil, especially when she plans to sacrifice her life for the resistance movement. As for him, the individual's happiness is a more important value. He even becomes involved with the resistance movement of Korean nationalists by attempting to carry out the assassination plan instead of Nansil, in order to gain recognition by and to be part of Nansil's world. On the other hand, Nansil suffers from agony caused by her relationship with Haemyŏng. Her love affair with Haemyŏng is arrayed as an antithesis to her pursuit of a collective good for Korea. Nansil is posited in a position in which she must choose between her personal happiness and the national interest. However, throughout the film, she strives to push away her individual desires and need for stability, for the sake of nationalism and in opposition to Japanese colonial rule, even though her individual desires such as taste for modern culture, and love toward Haemyŏng are not merely camouflage. It is also important to note that Nansil, whose dreams and talents are geared to modern popular music and dance, has suppressed her desire to pursue it as her profession. As for Nansil, her resistance activity on behalf of nationalism is a more significant goal to achieve than pursuing her talent under Japanese colonial rule. The love relationship between Haemyŏng and Nansil colludes with the prioritization of nationalism over individual desires. In the end, Nansil chooses nation over personal happiness represented by her love toward Haemyŏng. Her decision is, however, not an explicit and committed decision, but is a strain and a serious predicament. Although Haemyŏng's voice, as it speaks for individual desire, is very convincing in the film, her path to nationalism through the sacrifice of those desires is constructed in order to seem more valuable and solemn.

Haemyŏng's transformation is, however, not quite fulfilled in being equated with Nansil and other resistant activists who are solely dedicated to the fight against Japanese colonial rule. His transformation starts with his empathy in line with Nansil. When he falls in love with Nansil, love can be the value that he can risk his life for, and for which he abandons the privilege that he has enjoyed. Despite the dangers and the humiliation that he goes through in his relationship with Nansil, he does not stop pursuing her. Whereas Nansil strives to deter Haemyŏng in order to continue her plan and prevent Haemyŏng from getting hurt, Haemyŏng volunteers to bomb the ceremony. His motivation to be involved is to be a part of Nansil's world in order to win Nansil's heart. Most of all, Haemyŏng knows that to be a spiritual and physical partner of Nansil, it 
is indispensable to be a nationalist himself. Terror Park, who is originally chosen to be an agent of the bombing and is rumored to be the husband of Nansil, is a strong rival that Haemyŏng should emulate. However, what he pursues is the realization of love in union with Nansil. When Haemyŏng finds out that Terror Park does not exist, and that Nansil will implement the assassination, Haemyŏng pursues Nansil and strives to prevent Nansil from sacrificing her life and to persuade her to leave for Manchuria where they can live happily together. His transformation into a nationalist at the end of the film after the death of Nansil suggests that Haemyŏng has found his true identity as a Korean, and that Koreans should fight against Japanese colonial rule for Korea's independence. However, it is difficult to say that the film prioritizes nationalism over the love and individual desire attached to it. The modern love that they are involved in is a phenomenon that has been produced, circulated, and consumed in the colonial modern cultural sphere continuously shaped through interaction with Japanese colonial rule. Ironically, the love that jeopardizes Nansil's full commitment to nationalism makes Haemyong see the oppressive side of Japanese colonial rule. The modern love that binds Haemyong with Nansil in colonial Korea in this sense displays how modernity, colonialism, and nationalism are intertwined. Love is the important allegory used to signify the nation that led Haemyŏng to join the nationalists. In the retrospective scene, Haemyŏng says that Nansil should release a musical record in Korean after the emancipation of Korea from Japan. As Nansil asks if Haemyŏng also would like Korea to be independent, Haemyŏng agrees without hesitation. As for Haemyŏng, nationalism is equated with the personality of Nansil and is something that contributes to her happiness.

\section{Conclusion}

In the film "Modern Boy," colonialism, modernity, and nationalism are arrayed within the story of a modern love circumventing the bounds of modern conventions. The narrative conflict is resolved when the nationalist discourse prevails in Nansil's self-sacrifice of killing Japanese colonial officials and in Haemyŏng's transformation and participation in the resistance movement against Japan. However, the love affair is a metaphor for that which hinders Nansil's path to nationalism, but it remains convincing and attractive by highlighting the claims of the individual's life and happiness over a collective cause such as nationalism. The film displays a rather ambivalent attitude towards Japanese colonial rule, which can be subsumed into neither nationalistic discourse nor colonial modernity. Although the film highlights the modernity of Kyŏngsŏng and its people who are mesmerized by modern culture under Japanese colonial rule, the narrative plot develops as Haemyŏng is transformed into a nationalist through his love affair with Nansil. His recognition of the suffering and oppression of Koreans in Japanese colonial Korea and his subsequent transformation are mediated through the experience of a modern love relationship. The film reflects the changing trends of 
contemporary South Korea by looking at the culture and everyday lives of colonial Korea, while side-stepping nationalistic discourse, but it also captures the oppressive side of Japanese colonial authority that operates in every corner of the public and private spheres. Kyŏngsŏng, in the colonial Korea represented by the film, is neither merely the gloomy and poverty-stricken place plundered by Japan, nor the symbol of modern development. Rather, colonial Korea is the arena where colonial authority operates through complicated webs of colonial surveillance, military force, and modern infrastructure, and Korean people shape their own identities by contesting and compromising with Japanese colonial rule.

\section{Bibliography}

Ahn, Yonson. "The Colonial Past in Post-colonial South Korea: Colonialism, Modernity and Gender." In Contested Views of a Common Past, edited by Steffi Richter. Frankfurt/New York: Campus Verlag, 2008, 173-175.

Cho, Hyŏngrae. "'Modŏn Poi Modŏn Kŏl Maŭmkkŏt Chŭlgira' Shingminji Sojae Yŏnghwa Pum" [" 'Modern Boy, Modern Girl, Enjoy As Much As You Can' The Boom of Films set in Colonial Korea"]. Kyŏnghyang Sinmun, October 2, 2008. http://bit.ly/1OCFDjj.

Cho, Younghan. "Colonial Modernity Matters?: Debates on Colonial Past in South Korea." Cultural Studies, 26, no. 5 (2012): 645-669.

Choi, Hyaeweol. The New Woman in Colonial Korea: A Sourcebook. New York: Routledge, 2015.

Chŏng, Yŏnt'ae. "'Singminji Kŭndaehwaron'Nonjaengŭi Pip'an'gwa Shin'gŭndaesaron Mosaek" ["'The Debate on the Theory of Colonial Modernization and Proposal for New Paradigm of Modern History"]. Ch'angjakkwa Pip'yŏng, 27, no. 1 (1999): 352-376.

Dong, Madeleine Yue. "Who Is Afraid of the Chinese Modern Girl?." In The Modern Girl Around the World, edited by The Modern Girl Around the World Research Group. Durham: Duke University Press, 2008, 194-219.

Eckert, Carter J. Offspring of Empire. Seattle: University of Washington Press, 1991.

Kim, Baek Yung. "Ruptures and Conflicts in the Colonial Power Bloc: The Great Keijo Plan of the 1920s." Korea Journal, 48, no. 3 (2008): 10-40.

Kim, Hunggyu. Kŭndaeŭi T'ükkwŏnhwarŭl Nŏmŏsŏ [Overcoming the Privilege of Modernity]. Seoul: Ch'angjakkwa Pip'yŏng, 2013.

Kim, Kyŏngil. Yŏsŏngŭi Kŭndae, Kŭndaeŭi Yŏsŏng [Women's Modernity, Women of Modernity]. Seoul: P'urŭnnyŏksa, 2004.

Kim, Sujin. Shinnyŏsŏng, Kündaeŭi Kwaing [The New Woman, the Excess of Modernity]. Seoul: Somyŏngch'ulp'an, 2009.

Kwŏn, Bodŭre. Yŏnaeŭi Sidae [Age of Love]. Seoul: Hyŏnshilmunhwayŏn'gu, 2003.

Lee, Hong Yung. "Introduction: A Critique of "Colonial Modernity." In Colonial Rule and Social Change in Korea 1910-1945, edited by Clark W. Sorensen, Yongch'ul Ha, and Hong Yung Lee. Seattle: University of Washington Press, 2013, 338.

Ro, Sang-ho. "Café Waitresses and Disharmony: 'Erotic Grotesque' Aestheticism in 1930s Colonial Korea." Journal of Alternative Perspectives in the Social Sciences, 4, no. 4 (2012): 729-756. 
Shin, Gi-Wook, and Michael Robinson. "Introduction: Rethinking Colonial Korea." In Colonial Modernity in Korea, edited by Gi-Wook Shin and Michael Robinson. Boston: Harvard University Press, 1999, 1-18.

Sŏ, Chiyŏng. "Shingminji Chosŏnŭi Modŏn'gŏl" ["The Modern Girl in Colonial Korea"]. Han'gukyǒsŏnghak, 22, no. 3 (2006): 199-228.

Yi, Sunghwan. "Shingminji Kŭndae'ŭi Yŏnghwajŏk Chaehyŏnŭl T'onghan Han'guk Sahoeŭi Inshik" ["The Perception of Korean Society Displayed in the Representation of 'Colonial Modernity' in Korean Film"]. Yŏnghwayŏn'gu, 41 (2009): 105-126.

Yi, Yŏngho. "'Naejaejŏk Palchŏnnon' Yŏksainshigŭi Kwejŏkkwa Chŏnmang" ["Genealogy and Prospect on the Perception of Indigenous Development Theory"]. Han'guksayŏn'gu, 152 (2011): 239-272.

Yun, Haedong. Shingminjiŭi Hoesaekchidae [The Gray Area in the Colony]. Seoul: Yŏksabip'yŏnsa, 2003. 